\title{
From the Himalayan region or the Malay Archipelago: Molecular dating to trace the origin of a fern genus Phymatopteris (Polypodiaceae)
}

\author{
LI ChunXiang $^{1 *}$, LU ShuGang ${ }^{2}$, MA JunYe ${ }^{1}$, SUN XiaoYan $^{1}$, GAI YongHua ${ }^{1}$, \\ BARRINGTON David $S^{3} \&$ YANG Qun ${ }^{1}$
}

\author{
${ }^{1}$ State Key Laboratory of Palaeobiology and Stratigraphy, Nanjing Institute of Geology and Palaeontology, Chinese Academy of Sciences, \\ Nanjing 210008, China; \\ ${ }^{2}$ Institute of Ecology and Geobotany, Yunnan University, Kunming 650091, China; \\ ${ }^{3}$ Pringle Herbarium, Department of Plant Biology, University of Vermont, Burlington, VT 05405, USA
}

Received March 26, 2012; accepted June 27, 2012; published online August 10, 2012

\begin{abstract}
Phymatopteris Pic. Serm., a derived polypodiaceous fern, is one of the many fern genera that still suffer from nomenclatural confusion. Its generic circumscription and phylogenetic relationships with other selligueoid ferns have been controversial, and its geographic origin, whether in the Himalayan region of continental Asia or in Malay Archipelago, is still unknown. A phylogeny of all selligueoid ferns based on 4 cpDNA ( $r b c L, t r n L-F, r p s 4$ and rps4-trnS) regions indicates that Phymatopteris is not monophyletic. Phymatopteris species are distributed in 5 well-supported clades that can be distinguished with frond-shape and frond-margin characters. All early-divergent species are from the Malaysian Archipelago, while the remaining species are all from the Himalayan region and form a recently diverged group that is largely unresolved, most likely having resulted from an explosive radiation. Divergence-time estimation suggests that the first diversification of selligueoid ferns occurred at ca. $27 \mathrm{Ma}$ in the Malaysian Archipelago, followed by migration into the Himalayan region around 20 Ma. The radiation of the Himalayan species occurred mostly within the last 20 million years, within the period of recent major uplifts of the Qinghai-Tibetan Plateau (between the early Miocene and the Pleistocene) and late-Cenozoic global cooling. Our evidence leads us to propose that the Malaysian Archipelago is the ancestral area for Phymatopteris.
\end{abstract}

Phymatopteris, rbcL, trnL-F, rps4, rps4-trnS, phylogeny, divergence time

Citation: $\quad \mathrm{Li} \mathrm{C} \mathrm{X,} \mathrm{Lu} \mathrm{S} \mathrm{G,} \mathrm{Ma} \mathrm{J} \mathrm{Y,} \mathrm{et} \mathrm{al.} \mathrm{From} \mathrm{the} \mathrm{Himalayan} \mathrm{region} \mathrm{or} \mathrm{the} \mathrm{Malay} \mathrm{Archipelago:} \mathrm{Molecular} \mathrm{dating} \mathrm{to} \mathrm{trace} \mathrm{the} \mathrm{origin} \mathrm{of} \mathrm{a} \mathrm{fern} \mathrm{genus} \mathrm{Phymatopteris}$ (Polypodiaceae). Chin Sci Bull, 2012, 57: 4569-4577, doi: 10.1007/s11434-012-5392-8

Phymatopteris was established by Pichi Sermolli in 1973 to replace Phymatopsis J. Smith, an illegitimate name. Phymatopteris, one of the many genera of ferns which still suffer from nomenclatural problems, has been confused with $\mathrm{Mi}$ crosorum [1], Crypsinus [2-4], and Selliguea [5]. Ching [6] treated Phymatopteris as a natural genus, a decision followed by most Chinese taxonomists [7-12]. However, most recent studies outside China have rejected Phymatopteris and transferred it, together with Crypsinus, to Selliguea [5,13-16]. Schneider et al. [17-19] reconstructed the phy-

\footnotetext{
*Corresponding author (email: cxli@nigpas.ac.cn)
}

logeny of the family Polypodiaceae, which yielded basic insights into the phylogeny of the genus, they included Phymatopteris in their selligueoid lineage, which comprises Arthromeris (T. Moore) J. Sm., Gymnogrammitis Ching ex Tardieu \& C. Chr., Polypodiopteris C. F. Reed, and Selliguea Bory as defined by Hovenkamp [5], but they did not sample the Phymatopteris species from continental Asia.

Just as there is little consensus about the generic treatment of Phymatopteris, relationships within the genus remain poorly understood. Ching [6] divided the genus into 2 series and 5 subseries based on characteristics of frond shape and frond margin, i.e. series Hastatae, including subseries 
Griffithianae and subseries Hastatae; and series Oxylobae, including subseries Oxylobae, subseries Ebenipedes, and subseries Malacodontes. Ching's treatment of the species [6] was largely adopted by Lu [7] who did not subdivide the genus into series and subseries. Shao et al. [9-12] accepted Ching's [6] Phymatopteris as a natural group and examined spore ornamentations, characters of scales, leaf epidermises, and leaf appendages, with the goal of identifying morphological characters for a revised classification. Their results suggested that the characteristics of the leaves, scales, and spores cannot serve as a criterion of distinguishing the series and subseries in Phymatopteris. It appears that additional characters are required to assess inter-relationships of the genera.

There are two distinct hypotheses for the origin and diversification of Phymatopteris. Ching [20] regarded Phymatopteris species to have their origin in the Himalayan region of continental Asia; he saw the Malay and Polynesian species in this alliance as being the result of later migration and speciation events. This idea, accepted by most Chinese fern researchers, is in opposition to the recent finding that the Malay Archipelago is the putative ancestral area for selligueoid ferns [19] including Phymatopteris, which is included in Selliguea in their circumscription.

With the goal of resolving the relationships and origin of Phymatopteris and its allied genera, we used characters from molecular markers to contribute a modern phylogeny for these ferns. A final decision on systematic treatment and a rigorously supported hypothesis for the historical biogeography of these ferns were our objectives.

\section{Materials and methods}

\subsection{Taxon sampling}

We sampled 65 accessions representing 24 species of Phymatopteris and 17 accessions representing 7 species from among its relatives (Arthromeris and Gymnogrammitis). Phymatopteris sampling included species from all described series and subseries of Ching [6], with multiple accessions for each species to assess intraspecific and geographic variation. We selected outgroup taxa from the drynarioid lineage based on its phylogenetic proximity to the selligueoid ferns [17-19]. Voucher and other information is shown in Table 1.

Table 1 Taxa examined and GenBank accession numbers ${ }^{\text {a) }}$

\begin{tabular}{|c|c|c|c|c|c|}
\hline Species & Voucher $^{\text {b) }}$ & $r b c L$ & $r p s 4^{\text {c) }}$ & $\operatorname{trn} L-F$ & Locality $^{\text {b) }}$ \\
\hline Aglaomorpha meyeniana Schott & & AY529153 & AY529185 & AY529470 & \\
\hline Arthromeris cyrtomioides S. G. Lu \& C. D. Xu & Lu S-G/R20 & JQ685377 & JQ685441 & JQ700454 & Gongshan, Yunnan \\
\hline Arthromeris lehmannii (Mett.) Ching & & AY096198 & AY096216 & AY459177 & \\
\hline Arthromeris lehmannii (Mett.) Ching & Lu S-G/K12 & JQ685379 & JQ685443 & JQ700456 & Lijiang, Yunnan \\
\hline Arthromeris lehmannii (Mett.) Ching & Lu S-G /SG70 & JQ685380 & JQ685444 & JQ700457 & Lushui, Yunnan \\
\hline Arthromeris lehmannii (Mett.) Ching & Lu S-G/W56 & JQ685381 & JQ685445 & JQ700458 & Ailaoshan, Yunnan \\
\hline Arthromeris mairei (Brause) Ching & Lu S-G/B25 & JQ685382 & JQ685446 & JQ700459 & Kunming, Yunnan \\
\hline Arthromeris mairei (Brause) Ching & Lu S-G/MLP9 & JQ685383 & JQ685447 & JQ700460 & Malipo, Yunnan \\
\hline Arthromeris mairei (Brause) Ching & Lu S-G/Y9 & JQ685384 & JQ685448 & JQ700461 & Guangnan, Yunnan \\
\hline Arthromeris mairei (Brause) Ching & Lu S-G/JU40 & JQ685385 & JQ6854499 & JQ700462 & Jizushan, Yunnan \\
\hline Arthromeris mairei (Brause) Ching & Lu S-G/YL5 & JQ685386 & JQ685450 & JQ700463 & Yulong, Yunnan \\
\hline Arthromeris tatsienensis (Franch. et Bureau.) Ching & Lu S-G/T8 & JQ685388 & JQ685452 & JQ700465 & Yingjiang, Yunnan \\
\hline Arthromeris wallichiana (Spreng.) Ching & & EU128500 & EU128507 & EU128516 & \\
\hline Arthromeris wallichiana (Spreng.) Ching & Lu S-G/B13 & JQ685389 & JQ685453 & JQ700466 & Kunming, Yunnan \\
\hline Arthromeris wallichiana (Spreng.) Ching & Lu S-G/R19 & JQ685390 & JQ685454 & JQ700467 & Ailaoshan, Yunnan \\
\hline Drynaria rigidula (Sw.) Bedd. & & AF470339 & AY096221 & AY083642 & \\
\hline Gymnogrammitis dareiformis (Hook.) Ching & & AY096201 & AY096219 & EU128517 & \\
\hline Gymnogrammitis dareiformis (Hook.) Ching & Lu S-G/K37 & JQ685391 & JQ685455 & JQ700468 & Lijiang, Yunnan \\
\hline Gymnogrammitis dareiformis (Hook.) Ching & Lu S-G/W38 & JQ685392 & JQ685456 & JQ700469 & Ailaoshan, Yunnan \\
\hline Gymnogrammitis dareiformis (Hook.) Ching & Lu S-G/V31 & JQ685393 & JQ685457 & JQ700470 & Wuzhishan, Hainan \\
\hline Phymatopteris albopes (C. Chr. et Ching) Pic. Serm. & Lu S-G/SG48 & JQ685394 & JQ685458 & JQ700471 & Pingbian, Yunnan \\
\hline Phymatopteris albopes (C. Chr. et Ching) Pic. Serm. & Lu S-G/T3 & JQ685395 & JQ685459 & JQ700472 & Pingbian, Yunnan \\
\hline Phymatopteris chrysotricha (C. Chr. ) Pic. Serm. & Lu S-G/SG77 & JQ685396 & JQ685460 & JQ700473 & Gongshan, Yunnan \\
\hline Phymatopteris conjuncta (Ching) Pic. Serm. & Lu S-G/Z13 & JQ685397 & JQ685461 & JQ700474 & Shennongjia, Hubei \\
\hline
\end{tabular}


(Continued)

\begin{tabular}{|c|c|c|c|c|c|}
\hline Species & Voucher $^{\text {b) }}$ & $r b c L$ & $r p s 4^{\text {c) }}$ & $\operatorname{trn} L-F$ & Locality ${ }^{\text {b) }}$ \\
\hline Phymatopteris crenatopinnata (C. B. Clarke) Pic. Serm. & Lu S-G B17 & JQ685399 & JQ685463 & JQ700476 & Kunming, Yunnan \\
\hline Phymatopteris crenatopinnata (C. B. Clarke) Pic. Serm. & Lu S-G JC2 & JQ685400 & JQ685464 & JQ700477 & Jianchuan, Yunnan \\
\hline Phymatopteris crenatopinnata (C. B. Clarke) Pic. Serm. & Lu S-G JU17 & JQ685401 & JQ685465 & JQ700478 & Jizushan, Yunnan \\
\hline Phymatopteris dactylina (Christ) Pic. Serm. & Lu S-G/SG51 & JQ685402 & JQ685466 & JQ700479 & Gongshan, Yunnan \\
\hline Phymatopteris dactylina (Christ) Pic. Serm. & Lu S-G/SG80 & JQ685403 & JQ685467 & JQ700480 & Gongshan, Yunnan \\
\hline Phymatopteris ebenipes (Hook.) Pic. Serm. & Lu S-G/A23 & JQ685404 & JQ685468 & JQ700508 & Daweishan, Yunnan \\
\hline Phymatopteris ebenipes (Hook.) Pic. Serm. & Lu S-G/JC3 & JQ685406 & JQ685470 & - & Jianchuan, Yunnan \\
\hline Phymatopteris ebenipes (Hook.) Pic. Serm. & Lu S-G/K14 & JQ685407 & JQ685471 & - & Lijiang, Yunnan \\
\hline Phymatopteris ebenipes (Hook.) Pic. Serm. & Lu S-G/LD5 & JQ685408 & JQ685472 & - & Ludian, Yunnan \\
\hline Phymatopteris ebenipes (Hook.) Pic. Serm. & Lu S-G/SG49 & JQ685409 & JQ685473 & JQ700482 & Lushui, Yunnan \\
\hline Phymatopteris ebenipes (Hook.) Pic. Serm. & Lu S-G/W43 & JQ685410 & JQ685474 & - & Ailaoshan, Yunnan \\
\hline Phymatopteris griffithiana (Hook.) Pic. Serm. & Lu S-G/K3 & JQ685411 & JQ685475 & JQ700483 & Lijiang, Yunnan \\
\hline Phymatopteris griffithiana (Hook.) Pic. Serm. & Lu S-G/D13 & JQ685412 & JQ685476 & JQ700484 & Ludian, Yunnan \\
\hline Phymatopteris griffithiana (Hook.) Pic. Serm. & Lu S-G/SG47 & JQ685414 & JQ685478 & JQ700486 & Lushui, Yunnan \\
\hline Phymatopteris griffithiana (Hook.) Pic. Serm. & Lu S-G/YL1 & JQ685415 & JQ685479 & JQ700487 & Yulong, Yunnan \\
\hline Phymatopteris hastata (Thunb.) Pic. Serm. & Lu S-G/SG54 & JQ685416 & JQ685480 & JQ700488 & Xuanwei, Yunnan \\
\hline Phymatopteris hastata f simplex (Christ) Ching & Lu S-G/Z5 & JQ685417 & JQ685481 & - & Shenrongjia, Hubei \\
\hline Phymatopteris integerrima Ching & Lu S-G/K2 & JQ685418 & JQ685482 & JQ700489 & Lijiang, Yunnan \\
\hline Phymatopteris integerrima Ching & Lu S-G/XZ150 & JQ685419 & JQ685483 & JQ700490 & Chayu, Xizang \\
\hline Phymatopteris magoensis (C. Chr.) Pic. Serm. & Lu S-G/D10 & JQ685420 & JQ685484 & JQ700491 & Kunming, Yunnan \\
\hline Phymatopsis malacodon (Hook.) Pic. Serm. & Lu S-G/JU18 & JQ685421 & JQ685485 & JQ700492 & Jizushan, Yunnan \\
\hline Phymatopsis malacodon (Hook.) Pic. Serm. & Lu S-G/LD8 & JQ685422 & JQ685486 & - & Ludian, Yunnan \\
\hline Phymatopteris oxyloba (Wall. ex Kunze) Pic. Serm. & Lu S-G/A22 & JQ685423 & JQ685487 & - & Daweishan, Yunnan \\
\hline Phymatopteris oxyloba (Wall. ex Kunze) Pic. Serm. & Lu S-G/DL3 & JQ685424 & JQ685488 & JQ700493 & Dali, Yunnan \\
\hline Phymatopteris oxyloba (Wall. ex Kunze) Pic. Serm. & Lu S-G/YP81 & JQ685425 & JQ685489 & JQ700494 & Yongping, Yunnan \\
\hline Phymatopteris pianmaensis W. M. Chu & Lu S-G/SG81 & JQ685426 & JQ685490 & JQ700495 & Gongshan, Yunnan \\
\hline Phymatopteris simplicifolia Ching & Lu S-G/XZ145 & JQ685429 & JQ685493 & JQ700498 & Chayu, Xizang \\
\hline Phymatopteris subebenipes (Ching) Pic. Serm. & Lu S-G/DL5 & JQ685430 & JQ685494 & JQ700499 & Dali, Yunnan \\
\hline Phymatopteris subebenipes (Ching) Pic. Serm. & Lu S-G/K1 & JQ685431 & JQ685495 & - & Dali, Yunnan \\
\hline Phymatopteris suboxyloba (Ching) Pic. Serm. & Lu S-G/SG79 & JQ685432 & JQ685496 & JQ700500 & Gongshan, Yunnan \\
\hline Phymatopteris stewartii (Bedd.) Pic. Serm. & Lu S-G/JC1 & - & JQ685497 & JQ700501 & Jianchuan, Yunnan \\
\hline Phymatopteris stewartii (Bedd.) Pic. Serm. & Lu S-G/JU19 & JQ685433 & JQ685498 & JQ700502 & Jizushan, Yunnan \\
\hline Phymatopteris stewartii (Bedd.) Pic. Serm. & Lu S-G/SG52 & JQ685434 & JQ685499 & - & Lushui, Yunnan \\
\hline Phymatopteris stracheyi (Ching) Pic. Serm. & Lu S-G/C64 & JQ685435 & JQ685500 & JQ700503 & Guangnan, Yunnan, \\
\hline Phymatopteris stracheyi (Ching) Pic. Serm. & Lu S-G/SG50 & JQ685436 & JQ685501 & JQ700504 & Lushui, Yunnan \\
\hline Phymatopteris tibetana (Ching et S. K. Wu) W. M. Chu & Lu S-G/XZ147 & JQ685437 & JQ685502 & JQ700505 & Chayu, Xizang \\
\hline Phymatopteris trisecta (Baker) Pic. Serm. & Lu S-G/B2 & JQ685438 & JQ685503 & JQ700506 & Kunming, Yunnan \\
\hline Phymatopteris trisecta (Baker) Pic. Serm. & Lu S-G/YL2 & JQ685439 & JQ685504 & JQ700507 & Yulong, Yunnan \\
\hline Platycerium wallichii Hook. & Lu S-G/Y23 & JQ685440 & JQ685505 & DQ164525 & Guangnan, Yunnan \\
\hline Polypodiopteris brachypoda (Copel.) C. F. Reed & & AY362557 & AY362621 & & \\
\hline Selliguea enervis (Cav.) Ching & & AY096200 & AY096218 & AY459178 & \\
\hline Selliguea feei Bory & & AY529170 & AY529192 & AY459179 & \\
\hline Selliguea feei Bory & & AY096199 & AY096217 & & \\
\hline Selliguea hellwigii (Diels) Hovenkamp & & EU128501 & EU128508 & EU128518 & \\
\hline Selliguea heterocarpa (Blume) Blume & & AY459172 & AY362619 & AY459180 & \\
\hline Selliguea laciniata (Bedd.) Hovenkamp & & AY529271 & AY529193 & AY529484 & \\
\hline Selliguea lanceola (Mett.) Ching & & AY459173 & AY459186 & AY459181 & \\
\hline Selliguea lateritia (Baker) Hovenkamp & & EU128502 & EU128509 & EU128519 & \\
\hline Selliguea plantaginea Brack. & & EU128503 & EU128510 & EU128520 & \\
\hline Selliguea triloba (Houtt.) M. G. Price & & AY459174 & AY459187 & AY459182 & \\
\hline
\end{tabular}

a) Circumscription of Species follows Flora Reipubicae Popularis Sinicae [7,21]. Accession numbers in boldface type for newly generated sequences. b) rps4 and rps4-trnS IGS are given together because they are submitted to GenBank as a continuous sequence. c) Voucher information for newly generated sequences. 


\subsection{DNA extraction, PCR amplification and DNA sequencing}

Total genomic DNA was extracted from $2 \mathrm{~g}$ of fresh or $1 \mathrm{~g}$ of silica-gel dried leaves using the CTAB procedure [22], and modified according to Shi et al. [23]. Based on phylogenetic studies of the selligueoid ferns [17-19], we selected four plastid sequences ( $r b c L, r p s 4, r p s 4-t r n S$, and $t r n L-F)$, the PCR amplification, sequencing, and assembly for the 4 plastid loci followed our established protocols [24,25]. A total of 184 sequences were generated specifically for this project and are available in GenBank (Table 1).

\subsection{Sequence alignments}

Sequence alignments were performed using Clustal X [26] and subsequently edited manually in BioEdit [27]. There were no insertions or deletions (indels) in the protein-coding $r b c L$ alignment (1331 bp in length), whereas both the rps4+rps4-trnS (1119 bp in length) and trnL-F (408 bp in length) alignments included indels, which were not encoded as characters. However, ambiguously aligned non-coding regions with very divergent sequences were excluded from all analyses. Gaps were treated as missing data.

\subsection{Data set combinability}

Using MrBayes version 3.1.2 [28], Bayesian Markov chain Monte Carlo (B/MCMC) analyses were run for each single locus data set using the same settings as for the combined data matrix analysis. The 4 majority-rule consensus topologies were inspected for topological conflicts using a threshold of 0.95 posterior probability or higher in the B/MCMC analyses. We observed no topological conflict among data sets and hence all three were combined into a single data set, only the phylogenetic and divergence time estimation results for the combined data matrix were presented here. The fourlocus combined data matrix contained 81 taxa and $2858 \mathrm{bp}$ (some taxa had missing data).

\subsection{Phylogenetic analyses of the combined data matrix}

Phylogenetic analyses were investigated by maximum parsimony (MP), maximum likelihood (ML), and Bayesian inference (BI) methods in PAUP* 4.0b10 [29], PHYML 3.0 [30], and MrBayes 3.1.2 [28] respectively. For MP analysis, unweighted analyses were performed by heuristic searches with tree-bisection-reconnection (TBR) branch swapping, the MulTrees in effect, steepest descent off using 1000 random taxon-addition replicates, and one tree held at each step during stepwise addition. Bootstrap analyses [31] were conducted to examine the relative level of support for individual clades on the cladograms for each search (MPBS), using 500 bootstrap replicates and the same tree search procedure as described above. For the ML and BI analyses, the best-fitting model of sequence evolution for each data was identified using the Akaike Information Criterion in Modeltest 3.07 [32]. The GTR+I+G model was selected for the combined data sets. Once the best sequence evolution model was determined, the ML analysis was performed for each data set, the parameters such as base-composition, Gamma-shape, and ratio of invariable sites were also estimated from Modeltest 3.07. Nodal support on the ML tree was estimated by the nonparametric bootstrap (500 replicates, MLBS). BI was conducted using MrBayes 3.1.2 with appropriate evolutionary models determined as described above and the default priors. We ran two concurrent Markov chain Monte Carlo analyses, each with 4 chains, sampling one tree every 100 generations over $2 \times 1000000$ generations, starting with a random tree. The first $25 \%$ of the sample trees (5000 trees) were discarded as "burn-in". At this point, the standard deviation of split frequencies was $<0.01$, indicating that convergence to a stationary distribution had been achieved. Tracer v.1.5 [33] was also used to assess the convergence and stationarity of BI parameter values. Posterior probabilities (PP) were used to estimate nodal support.

\subsection{Divergence time estimation}

A likelihood-ratio test using the baseml program implemented in PAML [34] rejected the presence of a molecular clock. Therefore, we used a Bayesian relaxed-clock method [35] to transform the ML phylogram into a chronogram. This was calibrated with the earliest divergence of the selligueoid ferns (31.9 Ma), as estimated in Schuettpelz and Pryer [36], because no unequivocally assignable fossil is currently available for calibrating the phylogeny of selligueoid ferns. To estimate divergence time, the Bayesian analyses were done with the estbranches and multidivtime programs available at http://statgen.ncsu.edu/thorne/multidivtime.html, according to the protocol descried in Rutschmann [37]. The results from another program, Phylobayes 3.3 [38] with different bounds (the soft bound) were also obtained for comparison.

\section{Results}

\subsection{Phylogenetic analysis}

The aligned 4-marker combined data matrix ( $r b c L, r p s 4$, trnL-F and rps4-trnS) included 2858 characters, 746 characters were variable. MP, ML and BI analyses of the 4 combined sequences resulted in nearly identical topologies, most differences were in statistical support values. Because the resultant topologies for relationships of the selligueoid ferns from each of the datasets were not in conflict with one another, the phylogenetic relationships presented here are based on analyses of the combined data set. The 50\% majorityrule consensus tree resulting from MP, ML and $\mathrm{BI}$ analyses of the four combined sequences data set is shown in Figure 1. These analyses yielded an almost robust phylogeny with 


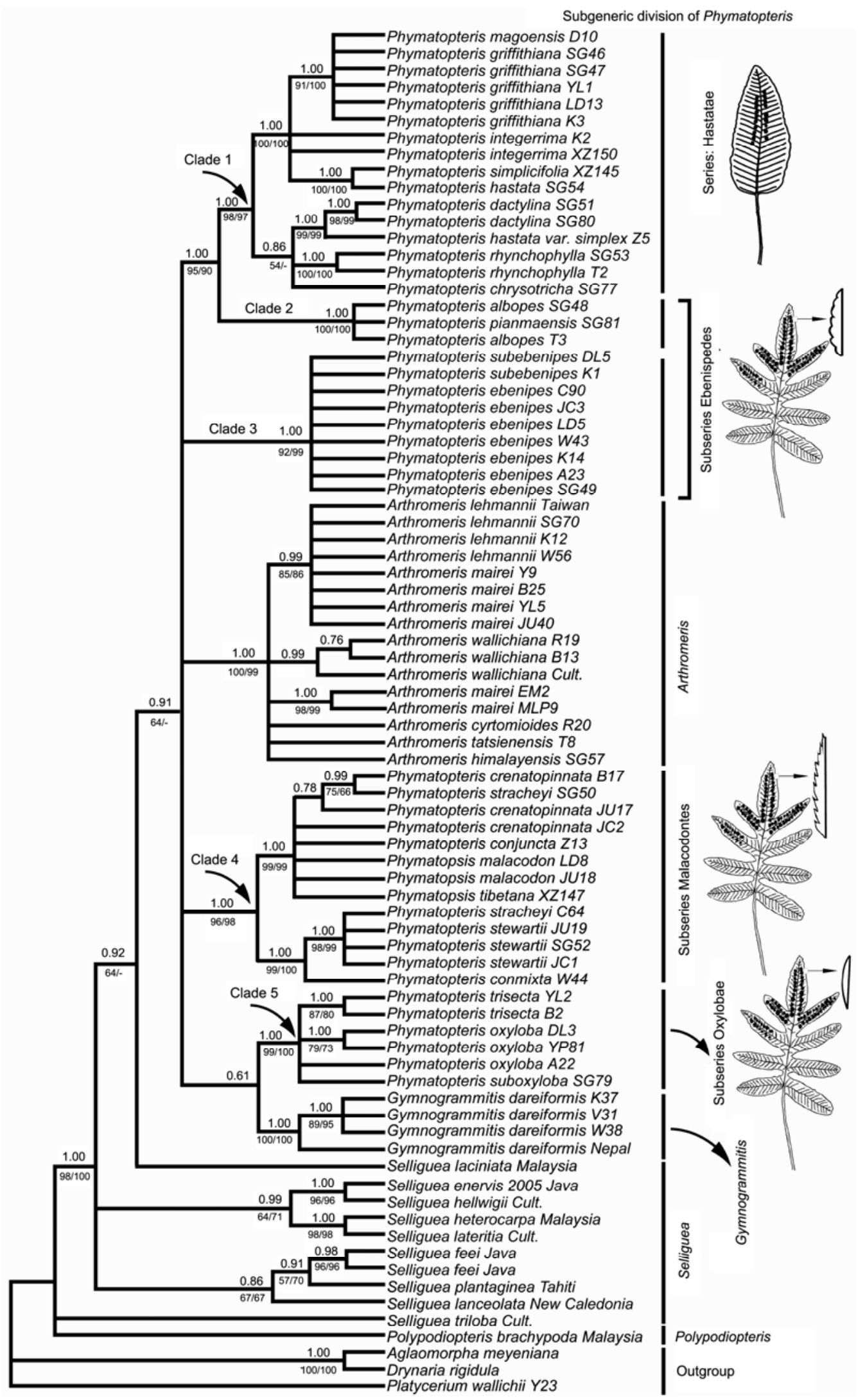

Figure 1 Fifty-percent majority-rule consensus tree from Bayesian inference (BI) of the 81-taxon phylogeny based on the combined $r b c L, t r n L-F, r p s 4$, and rps4-trnS sequence data. The tree from maximum likelihood (ML) and maximum parsimony (MP) has identical topology. Values above branches are posterior probability from $\mathrm{BI}$; values below branches are bootstrap percentage $\geqslant 50 \%$ from MP and ML analyses. Five clades and subgeneric division within Phymatopteris and characteristics of the frond shape and the frond margin are marked in the phylogenetic tree. 
the exception of a few nodes.

Together, Polypodiopteris and all Selliguea species constitute a suite of clades basal to the rest of selligueoid ferns. The Selliguea species are all from the Malay Archipelago except for $S$. plantaginea, which is from the Pacific islands. The Selligueas have simple fronds (S. lanceolata, S. plantaginea, S. feei, S. lateritia, S. heterocarpa, and S. enervis), trilobed fronds (Selliguea triloba), or pinnatifid fronds (S. laciniata). The rest of the selligueoid ferns analyzed here constitute a single monophyletic group-sister to the Malaysian S. laciniata-which in turn comprises seven unresolved clades. These clades, all from continental Asia in their geographic distribution (Figure 2), comprise the 5 Phymatopteris clades (labeled as clades 1-5), the Arthromeris clade, and the Gymnogrammitis clade. Strong support was obtained for each of the 7 clades ( $\mathrm{PP}=1.00$ and MLBS, MPBS $\geqslant 95 \%$ ). The 5 well-supported clades of Phymatopteris species have consistent morphological characteristics of frond shape and frond margin [6]. Clade 1, comprising species of Series Hastatae, had simple fronds; clades 2 and 3, comprising all species in subseries Ebenipedes, had pinnate to pinnatifid fronds with marginal sinuses; Clade 4, comprising species in subseries Malacodontes, had pinnate to pinnatifid fronds with serrate margins; Clade 5, comprising species in subseries Oxylobae, had pinnate to pinnatifid fronds with entire margins. The phylogenetic results lead us to suggest that selligueoid ferns diverged first in the Malay Archipelago and that the clades including Phymatopteris and its relatives in continental Asia have evolved more recently.

\subsection{Divergence times}

The estimated divergence times for the nodes of the phylogeny are summarized in Figure 2. Basal divergence (the first diversification) in the selligueoid ferns is estimated to have occurred at ca. $27 \mathrm{Ma}$; diversification of the crown lineage of Phymatopteris, Arthromeris and Gymnogrammitis occurred at ca. 22 Ma. Five clades of Phymatopteris subsequently diverged between ca. 5-18 Ma, while, clades of Selliguea diverged between ca. 19-24 Ma. Arthromeris and Gymnogrammitis originated at ca. 14 and 12 Ma respectively. The lower-latitude Selliguea lineages in the Malay Archipelago originated relatively early, while the higherlatitude taxa in the Himalayan region originated relatively recently. Divergence time estimates indicate that Phymatopteris lineages in the Himalayan region are not older than that of Selliguea lineages in the Malay Archipelago.

\section{Discussion}

\subsection{Phylogenetic relationships}

Both Phymatopteris sensu Ching [6] and Selliguea sensu Hovenkamp [5] are not monophyletic. Phymatopteris is polyphyletic because two genera, Gymnogrammitis and
Arthromeris, were nested within the clade including all sampled Phymatopteris species. The 10 sampled species of Selliguea sensu Hovenkamp resolved in three lineages paraphyletic to the clade including all sampled Phymatopteris, Gymnogrammitis, and Arthromeris species. Thus the 5 clades of Phymatopteris sensu Ching [6] we resolved lie in a different clade from paraphyletic Selliguea sensu Hovenkamp. Different base chromosome numbers can also be used to distinguish these two lineages [8]. Consequently, the inclusion of Phymatopteris in Selliguea [5,13-16] seems unwise. Phymatopteris is resolved as polyphyletic in the current work; at least Gymngrammitis must be included in Phymatopteris to render it monophyletic. Full resolution of the Phymatopteris clade will reveal the best disposition of Arthromeris, at present part of an unresolved polytomy among the Phymatopteris clades. In any case, Phymatopteris should be treated as a separate genus from Selliguea as proposed by Ching [6]. For the alternative classification of the acceptance of a single genus Selliguea, Gymngrammitis and Arthromeris must be included in Selliguea based on the present phylogeny.

An increase of taxonomic coverage as well as the addition of molecular markers is important for delineating the two putatively unnatural genera Selliguea and Phymatopteris. Some species, e.g. the type species, Phymatopteris palmata (Blume) Pic. Serm., still need to be included in phylogenetic studies. The addition of morphological and developmental characteristics from living materials, in the context of a fully resolved phylogeny, will provide the basis for a revised classification of this enigmatic group.

\subsection{Biogeographic history of selligueoid ferns}

Selligueoid ferns are most diverse in tropical and subtropical southeast Asia [5,20]. Two genera in this alliance, Gymnogrammitis and Arthromeris, occur exclusively or nearly exclusively in subtropical to tropical southeast Asia, whereas Selliguea sensu Hovenkamp [5] has a wider distribution in southeast Asia, including Malaysia and Polynesia. Ching [6] believed that Phymatopteris included more than 60 species from mainland Asia, most of them from China and adjacent countries, and Phymatopteris species have their origin in the Himalayan region of continental Asia. He proposed that the Malay and Polynesian species in this alliance are the result of later migration and speciation events [20]. Our phylogeny indicates an origin of selligueoids in the Asiatic tropics with putative deep splits separating predominantly Malay clades from predominantly continental Asiatic clades (Figure 2). Five clades of Phymatopteris originated between ca. 5-18 Ma, i.e. more recently than the 3 clades of Selliguea, which originated between ca. 19$24 \mathrm{Ma}$. The radiation of Phymatopteris lineages in continental Asia is newer than that of Selliguea in the Malay Archipelago, suggesting expansion from the tropics into the Himalayan region. 


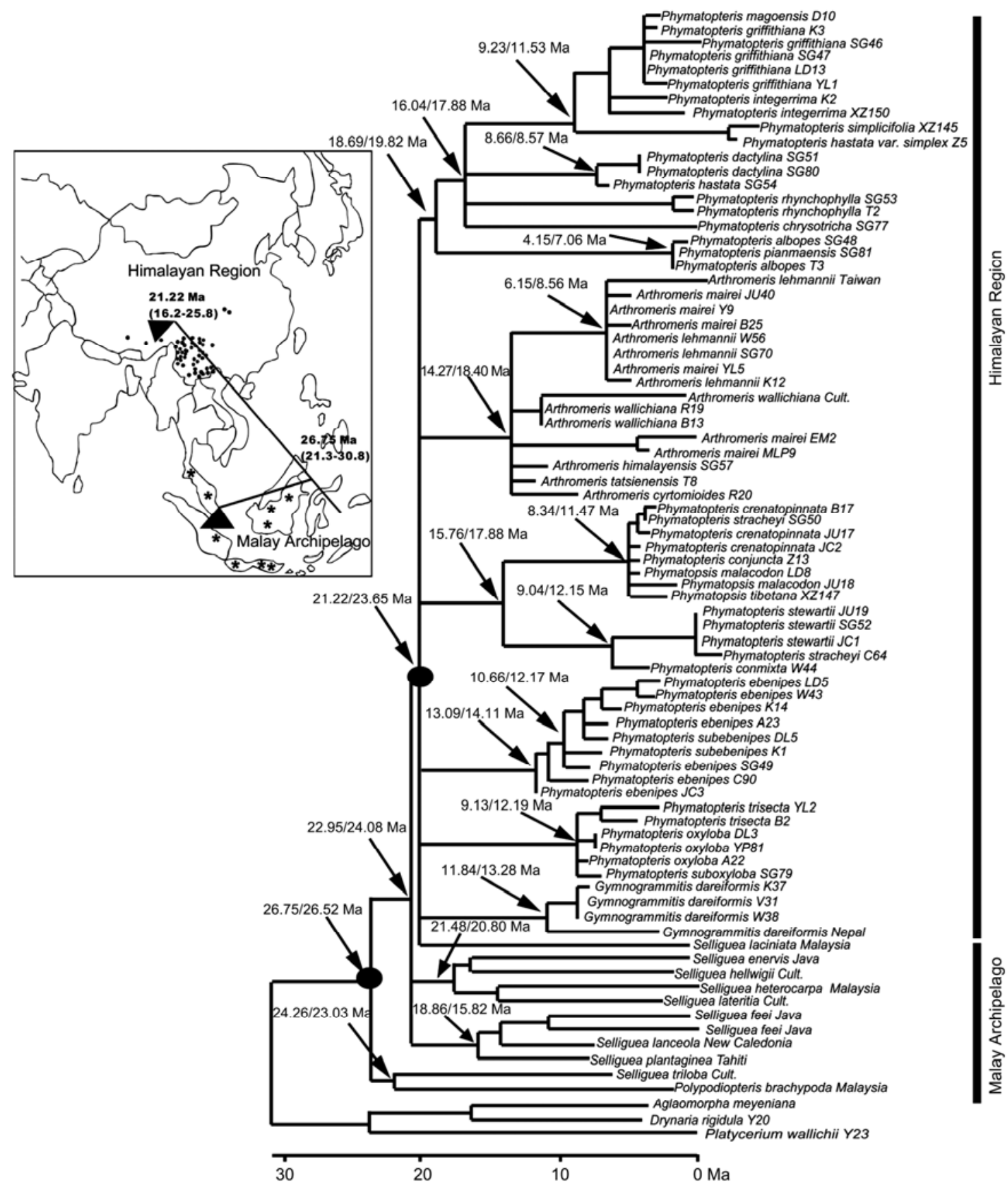

Figure 2 Distributions of Phymatopteris $(\bullet)$ and Selliguea $(*)$ and the hypothesized diversifications indicated by arrows based on cpDNA sequence information from extant species (left). Simplified chronogram generated by applying Bayesian relaxed-clock to the ML phylogeny shown in Figure 1, values ( / ) above branches are the estimated divergence times from multidivtime and Phylobayes programs (right). Two main diversifications are labeled with black circles in the phylogenetic tree $(\bullet)$.

\subsection{Diversification in Himalayan region}

The Himalayan region had undergone dramatic geologic changes during the Tertiary and the Quaternary. The Tibetan Plateau, warm and humid in the early Tertiary, arose rapidly in the Miocene and reached the present height before the Pliocene [39-41]. Climatic oscillations in the Pliocene and in the Quaternary, along with Pleistocene advances/ retreats of glaciers, are critical to understanding evolutionary change in this region. Divergence estimations indicate that divergence within the five clades of Phymatopteris took place during the major uplift of the Tibetan Plateau, suggesting that orogeny and accompanying climate change are central in this history. Though the crown lineage of Phymatopteris, including Arthromeris and Gymnogrammitis are morphologically distinct, the phylogenetic relationships within this lineage are complex and largely unresolved (i.e. lower statistical support along the backbone of this lineage). This 
poor resolution may be a signature of explosive speciation or rapid radiation as in some other floras [42-44].

\subsection{Frond evolution in selligueoid ferns in an ecological context}

We found that two main diversifications occur in the selligueoid ferns. Early divergences yielded the Selliguea lineages in the Malay Archipelago, most of the species in this lineage have simple fronds (S. lanceola, S. plantaginea, S. feei, S. lateritia, S. heterocarpa, and S. enervis). Only $S$. triloba has trilobed fronds and $S$. laciniata pinnatifid fronds. In fact, nearly 90\% Selliguea sensu Hovenkamp [5] in Malay Archipelago have simple fronds. The more recent diversification of the crown lineage including Phymatopteris, Arthromeris and Gymnogrammitis (in continental Asia) by contrast, has yielded species with pinnatifid fronds with diverse lamina margins. Only ca. 15\% Phymatopteris species have simple fronds [6]. Thus, the early events in evolution yielded plants with simple fronds at lower latitudes in the tropical Malay Archipelago. In contrast, more recent events have yielded a suite of species that tend to have pinnatifid fronds and occupy higher-latitude regions. With our improved understanding of frond morphological variation in selligueoid ferns, we will move on to exploring the patterns of speciation within the Himalayan region and the Malay Archipelago.

We are grateful to Prof. Shi Suhua (Sun Yat-sen University, Guangzhou, China) and two anonymous reviewers for their valuable discussions. This work was supported by the Knowledge Innovation Project of the Chinese Academy of Science (KZCX2-YW-JC104, KZCX2-YW-155), the National Natural Science Foundation of China (40972001, 30970186), and State Key Laboratory of Palaeobiology and Stratigraphy (Y026150112, NIGPAS).

1 Copeland E B. Genera Filicum. Waltham Massachusetts: Chronia Botanica Company, 1947. 1-247

2 Holttum R E. A Revised Flora of Malaya, Vol. II. Ferns of Malaya. Singapore: Government Printing Office, 1954. 197

3 Cheng X. Crypsinus C. Presl. In: Cheng X, Wu S G, Lu S G, eds. Flora Yunnanica. Beijing: Science Press, 2005. 370

4 Cheng X. Systematic study of Crypsinus Presl. (Polypodiaceae) in eastern Asia. In: Verma S C, Khullar S P, Cheema H K, eds. Perspectives in Pteridophytes. Dehra Dun, India: Bishen Singh Mahendra Pal Singh, 2008. 35-60

5 Hovenkamp P. An account of the Malay-Pacific species of Selliguea (Polypodiaceae). Blumea, 1998, 43: 1-108

6 Ching R C. On the genera Phymatopsis J. Sm. and Crypsinus Presl. Acta Phytotax Sin, 1964, 9: 179-197

7 Lu S G. Phymatopteris Pic Serm. Flora Reipublicae Popularis Sinicae, Vol. 6(2). Beijing: Science Press, 2000. 161-200

8 Shao W, Lu S G. First recognition of the genus Crypsinus (Polypodiaceae) in China. Acta Bot Yunnan, 2009, 29: 29-31

9 Shao W, Shang Q C, Lu S G. Ecological significance of leaf appendage in the fern genus Phymatopteris Pichi-Serm. (Polypodiaceae). Guihaia, 2010, 30: 339-342

10 Shao W, Shang Q C, Lu S G. Spore ornamentation of 22 species in the fern genus Phymatopteris Pichi-Serm. under SEM. Acta Bot Boreal Occident Sin, 2010, 30: 524-529

11 Shao W, Lu S G, Shang Q C. Taxonomic significance of scale characteristics in the fern genus Phymatopteris (Polypodiaceae). Guihaia,
2011, 31: 14-19

12 Shao W, Lu S G, Shang Q C. Comparative morphology of leaf epidermis in the fern genus Phymatopteris (Polypodiaceae). Plant Diver Resour, 2011,33: 174-182

13 Hennipman E, Veldhoen P, Kramer K U, et al. Polypodiaceae. In: Kubitzki K, ed. The Families and Genera of Vascular Plants. Berlin: Springer-Verlag, 1990. 214

14 Tryon A F, Lugardon B. Spores of Pteridophytes. New York: Springer, 1991. 356-357

15 Smith A R, Pryer K M, Schuettpelz E, et al. A classification of extant ferns. Taxon, 2006, 55: 705-731

16 Smith A R, Pryer K M, Schuettpelz E, et al. Fern classification. In: Ranker T A, Haufler C H, eds. Biology and Evolution of Ferns and Lycophytes. Cambridge: Cambridge University Press, 2008. 417-467

17 Schneider H, Smith A R, Cranfill R, et al. Gymnogrammitis dareiformis is a polygrammoid fern (Polypodiaceae) - resolving an apparent conflict between morphologicaland molecular data. Plant Syst Evol, 2002, 234: 121-136

18 Schneider H, Smith A R, Cranfill R, et al. Unraveling the phylogeny of polygrammoid ferns (Polypodiaceae \& Grammitidaceae): Exploring aspects of the diversification of epiphytic plants. Molec Phylogenet Evol, 2004, 31: 1041-1063

19 Schneider H, Kreier H P, Hovenkamp P, et al. Phylogenetic relationships of the fern genus Christiopteris shed new light onto the classification and biogeography of drynarioid ferns. Bot J Linn Soc, 2008, 157: 645-656

20 Ching R C. The Himalaya as a centre of concentration for the south-eastern Asiatic polypodiaceous ferns. Acta Bot Yunnan, 1979, 1: 23-31

21 Xu C D, Lu S G. Arthromeris cyrtomioides S. G. Lu \& C. D. Xu, a new species of Polypodiaceae from Yunnan, China. Acta Phytotax Sin, 2007, 45: 82-85

22 Doyle J, Doyle J. A rapid DNA isolation procedure for small quantities of fresh leaf tissue. Phytochem Bull, 1987, 19: 11-15

23 Shi S H, Zhang Q, Chen Y Q, et al. A simple method for isolation of total RNA and DNA from silicagel-dried and fresh leaves of plants (in Chinese). Acta Sci Nat Univ Sunyatseni, 1996, 35: 103-105

24 Li C X, Lu S G, Yang Q. Asian origin for Polystichum (Dryopteridaceae) based on $r b c L$ sequences. Chin Sci Bull, 2004, 49: 1146-1150

25 Li C X, Lu S G, Barrington D S. Chloroplast trnL-trnF and rps4-trnS sequences reveal origin and diversification of Chinese Polystichum (Dryopteridaceae). J Plant Res, 2008, 21: 19-26

26 Thompson J D, Gibson T J, Plewniak F, et al. The ClustaX windows interface: Flexible strategies for multiple sequences alignment aided by quality analysis tools. Nucleic Acids Res, 1997, 24: 4876-4882

27 Hall T A. BioEdit: A user-friendly biological sequence alignment editor and analysis program for Windows 95/98/NT. Nucleic Acids Symp Ser, 1999, 41: 95-98

28 Ronquist F, Huelsenbeck J P. MrBayes 3: Bayesian phylogenetic inference under mixed models. Bioinformatics, 2003, 19: 1572-1574

29 Swofford D L. PAUP* Phylogenetic Analysis Using Parsimony (* and other methods), Version 4.0b10. Sinauer Associates, Sunderland, 2002

30 Guindon S, Gascuel O. A simple, fast, and accurate algorithm to estimate large phylogenies by maximum likelihood. Syst Biol, 2003, 52: 696-704

31 Felsenstein J. Evolutionary trees from DNA sequences: A maximum likelihood approach. J Mol Evol, 1981, 17: 368-376

32 Posada D, Crandall K A. Modeltest: Testing the model of DNA substitution. Bioinformatics, 1998, 14: 817-818

33 Rambaut A, Drummond A J. Tracer, 2007, available from: http: //beast.bio.ed.ac.uk/tracer/

34 Yang Z. PAML: A program package for phylogenetic analysis by maximum likelihood. Comput Appl Biosci, 1997, 13: 555-556

35 Thorne J L, Kishino H. Divergence time and evolutionary rate estimation with multilocus data. Syst Biol, 2002, 51: 689-702

36 Schuettpelz E. Pryer K M. Evidence for a Cenozoic radiation of ferns in an angiosperm-dominated canopy. Proc Nat Acad Sci USA, 2009, 106: $11200-11205$ 
37 Rutschmann F. Bayesian molecular dating using PAML/multidivtime. A step-by-step manual. University of Zurich, Switzerland, 2005

38 Lartillot N, Lepage T, Blanquart S. PhyloBayes 3: A Bayesian software package for phylogenetic reconstruction and molecular dating. Bioinformatics, 2009, 25: 2286-2288

39 Harrison T M, Copeland P, Kidd W S F, et al. Rising Tibet. Science, 1992, 255: 1663-1670

40 Peng Z, Ho S Y W, Zhang Y, et al. Uplift of the Tibetan Plateau: Evidence from divergence times of glyptosternoid catfishes. Mol Phylogenet Evol, 2006, 39: 568-572

41 Wang C, Zhao X, Liu Z, et al. Constraints on the early uplift history of the Tibetan Plateau. Proc Natl Acad Sci USA, 2008, 105: 49874992

42 Richardson J E, Pennington R T, Pennington T D, et al. Rapid diver-sification of a species-rich genus of neotropical rain forest trees. Science, 2001, 2242-2245

43 Richardson J E, Weitz F M, Fay M F, et al. Rapid and recent origin of species richness in the Cape flora of South Africa. Nature, 2001, 412: 181-183

44 Li C X, Lu S G. Phylogeny and divergence of Chinese Angiopteridaceae based on chloroplast DNA sequence data $(r b c L$ and $t r n L-F)$. Chin Sci Bull, 2007, 52: 91-97

Open Access This article is distributed under the terms of the Creative Commons Attribution License which permits any use, distribution, and reproduction in any medium, provided the original author(s) and source are credited. 